\title{
The UK Ministry of Defence Project Orientated Environmental Management System (POEMS)
}

\author{
Erick Galante $^{[\mathrm{a}]}$, Tracey Temple ${ }^{[\mathrm{b}]}$, Melissa Ladyman ${ }^{[\mathrm{a}]}$, Philip P. Gill ${ }^{[\mathrm{a}]}$
}

\begin{abstract}
The Project Orientated Environmental Management System (POEMS) is the UK Ministry of Defence (MOD) bespoke environmental management system for the acquisition and use of equipment. The full implementation of a site-specific environmental management system is challenging for the MOD because there are many permanent MOD sites with transient populations, frequently changing site activities and diverse types of equipment. Nevertheless, MOD policy requires that all sites are covered by an environmental management system. POEMS is based on international standards ISO14001 and ISO14040, which focus on environmental management systems and life cycle assessment, respectively. The primary aim of POEMS is to identify and manage any environmental aspects (causes) and impacts (effects) by scrutinising MOD equipment and activities during acquisition, operation and disposal ('from cradle to grave'). This is achieved by drawing up a priority list of activities associated with the equipment based on anticipated environmental impact scores, resulting in an environmental management plan that spans the life cycle of the equipment and any corresponding activities. This article describes the POEMS procedure for both experts and non-experts, and demonstrates the implementation of POEMS using a 105-mm howitzer artillery round as a theoretical case study. The results anticipated at each stage of the POEMS procedure are discussed in detail, and the documentation necessary to verify the correct application of POEMS is demonstrated.
\end{abstract}

Keywords: POEMS, environmental management system, life cycle assessment, International Organization for Standardization, UK Ministry of Defence

\section{Introduction}

An environmental management system (EMS) is a comprehensive, planned and documented system that integrates procedures and processes for monitoring and reporting environmental performance. The primary aim of an EMS is to identify any environmental aspects (causes) and impacts (effects) by scrutinising activities that may be detrimental to the environment. An EMS also helps an organisation to comply with environmental laws and policies, and organisations may choose to become accredited by an external standard-setting body such as the International Organization for Standardization (ISO), the EcoManagement and Audit Scheme (EMAS), or the British Standards Institution (BSI) Group. Registration with these organisations is voluntary, but is often valuable from a reputational and business perspective [1], [2].

[a] E.B.F. Galante

M.K. Ladyman

P.P. Gill

Centre for Defence Chemistry

Cranfield University

Defence Academy of the United Kingdom, Shrivenham, SN6 7LA, UK

[b] T. J. Temple - -Corresponding Author

Centre for Defence Chemistry

Cranfield University

Defence Academy of the United Kingdom, Shrivenham,

SN6 $7 L A$, UK

Fax: $(+)$

E-mail:t.temple@cranfield.ac.uk
An EMS can be implemented throughout a site or company, or can be restricted to individual areas or business sectors.

The full implementation of a site-specific EMS standard is challenging for the UK Ministry of Defence (MOD) because there are many permanent MOD sites with transient populations and frequently changing site activities and equipment [3], [4]. Nevertheless, MOD policy requires that all sites are covered by an EMS based on ISO 14001 [5], the EMS standard. Therefore, a different environmental management approach is applied during the acquisition of new MOD equipment, which can range from fitting out a new office to the commission of a new fleet of ships. The MOD has developed a bespoke platform known as the Project Orientated Environmental Management System (POEMS) [6], which was designed to facilitate the application of EMS to specific MOD activities and equipment throughout the life cycle.

POEMS is based on the international standards ISO 14001 [5] and ISO 14040 [7], the former representing the cornerstone of EMS and the latter covering life cycle assessment (LCA). LCA is a technique for assessing the environmental impact of product throughout the entire lifecycle from extraction of raw materials to disposal, often referred to as cradle to grave. In recent years there has been increasing interest in cradle to cradle thinking, which integrates the end of life product back into manufacture (cradleto-cradle) [7]-[9]. POEMS also incorporates elements from the US Department of Defence's Military Standard 882, entitled Standard Practice for System Safety [10]-[12]. POEMS involves eight major procedures, known as Environmental Management Procedures (EMPs), that can be implemented in numerical order or in whichever order is most convenient in terms of the information available, making it a flexible approach. POEMS can be mapped onto the guidelines in ISO 14001 [5] and ISO 14040 [7] as shown in Table 1. 
Table 1 Alignment of POEMS EMP's to ISO 14001 and ISO14040 guidelines

\begin{tabular}{|c|c|c|}
\hline \multirow{2}{*}{ POEMS EMPS } & \multicolumn{2}{|c|}{$\begin{array}{l}\text { Equivalent guidelines from ISO } \\
\text { standards }\end{array}$} \\
\hline & ISO 14001 & ISO 14040 \\
\hline \multirow{3}{*}{$\begin{array}{l}\text { EMP01: } \\
\text { Stakeholders and } \\
\text { standards } \\
\text { identification }\end{array}$} & $\begin{array}{l}\text { Identification of } \\
\text { compliance } \\
\text { requirements }\end{array}$ & \multirow{3}{*}{ No equivalent } \\
\hline & $\begin{array}{l}\text { Define resources, } \\
\text { roles, } \\
\text { responsibilities and } \\
\text { authorities }\end{array}$ & \\
\hline & $\begin{array}{l}\text { Communication } \\
\text { plan }\end{array}$ & \\
\hline $\begin{array}{l}\text { EMP02: Screening } \\
\text { and scoping }\end{array}$ & $\begin{array}{l}\text { Identification of } \\
\text { aspects and } \\
\text { impacts }\end{array}$ & $\begin{array}{l}\text { Define scope and } \\
\text { system boundaries }\end{array}$ \\
\hline $\begin{array}{l}\text { EMP03: Impact } \\
\text { priority evaluation }\end{array}$ & $\begin{array}{l}\text { Identification of } \\
\text { significant impacts } \\
\text { organisation may } \\
\text { cause }\end{array}$ & No equivalent \\
\hline $\begin{array}{l}\text { EMP04: } \\
\text { Environmental } \\
\text { impact assessment } \\
\text { (EIA) plan }\end{array}$ & No equivalent & $\begin{array}{l}\text { Data quality } \\
\text { requirements }\end{array}$ \\
\hline $\begin{array}{l}\text { EMP05: EIAs and } \\
\text { reporting }\end{array}$ & No equivalent & $\begin{array}{l}\text { Life cycle impact } \\
\text { assessment }\end{array}$ \\
\hline $\begin{array}{l}\text { EMP06: } \\
\text { Environmental } \\
\text { management plan } \\
\text { (objectives and } \\
\text { targets) }\end{array}$ & $\begin{array}{l}\text { Identification of } \\
\text { objectives and } \\
\text { targets with their } \\
\text { environmental } \\
\text { management plan }\end{array}$ & $\begin{array}{l}\text { Life cycle } \\
\text { interpretation }\end{array}$ \\
\hline $\begin{array}{l}\text { EMP07: Operational } \\
\text { controls }\end{array}$ & $\begin{array}{l}\text { Development of } \\
\text { document and } \\
\text { operational control } \\
\text { procedures, } \\
\text { development of } \\
\text { emergency } \\
\text { procedure plans }\end{array}$ & No equivalent \\
\hline \multirow[t]{2}{*}{$\begin{array}{l}\text { EMP08: Continuous } \\
\text { review }\end{array}$} & $\begin{array}{l}\text { Monitor and } \\
\text { measure } \\
\text { environmental } \\
\text { impact }\end{array}$ & \multirow[t]{2}{*}{ Critical review } \\
\hline & $\begin{array}{l}\text { Evaluate } \\
\text { compliance }\end{array}$ & \\
\hline Audit & $\begin{array}{l}\text { Management of } \\
\text { non-conformance, } \\
\text { preventative } \\
\text { actions; records } \\
\text { management; } \\
\text { internal audit, } \\
\text { management } \\
\text { review }\end{array}$ & No equivalent \\
\hline
\end{tabular}

As part of the POEMS implementation process, the environmental impact is assessed throughout the life cycle of the equipment or activity using a qualitative ranking system, which is similar to ISO 14040. In POEMS, LCA is represented by the CADMID cycle (concept, assessment, demonstration, manufacture, in service, disposal), which describes the lifetime of a system from cradle to grave (Figure 1), or if practicable from cradle-to-cradle.

The first four POEMS EMPs allow the assessment of potential causes of environmental damage (aspects) and their effects (impacts) at each relevant step in the CADMID cycle. EMPs 01-04 include data gathering steps such as compiling stakeholder and standards registers, gaining an understanding of the equipment and setting the boundaries for POEMS implementation. It also includes the development of a priority list for the associated activities and their environmental impacts. The next three procedures (EMPs 05-07) describe how to develop an Environmental Management Plan spanning the life cycle of the equipment or activity. The final procedure (EMP08) is a continuous review process to ensure any changes are captured during the lifecycle of the equipment. As stated earlier, POEMS is intentionally designed to be flexible, and this can be demonstrated by applying it to legacy equipment that may already be in service, as well as commercial off-the-shelf products and conceptual projects. Regardless of the CADMID phase, POEMS should be carried out for all future phases. Any inservice equipment should have an Environmental Management Plan that details all in-service activities, including maintenance, mid-life upgrades and 'business as usual' processes, as well as a disposal plan.

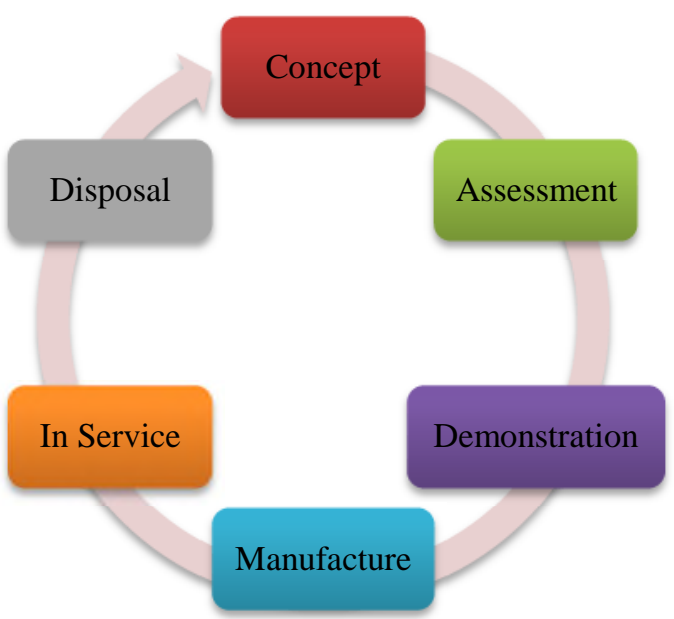

Figure 1: Diagram of the CADMID cycle

The Environmental Management Plan is not the end of the process. Once POEMS has been completed and the environmental targets have been set, a plan must be put in place for reviews. These may take the form of internal and external audits, or may be triggered by certain events during the life cycle such as a mid-life upgrade, which may introduce new materials and therefore require an updated disposal plan.

Here we describe the implementation of the eight core POEMS procedures to a 105-mm howitzer high-explosive artillery round stored and used at a theoretical UK training base. We have focussed on the in-service phase because the earlier stages, including manufacture, are complete and can no longer be influenced by LCA. However, the EMS element may be able to influence certain aspects of the supply chain for future manufacturing, as well as the disposal of waste products. The main purpose of this article is to provide guidance that both experts and non-experts can use to implement POEMS, using a theoretical case study to illustrate key aspects of the procedure and documentation. 


\section{Case Study: 105-mm round}

The 105-mm howitzer artillery round is routinely used for training at a range in the southwest of England, and for the purposes of this article we are assuming that training with the round will increase in the future. The following sections outline a hypothetical yet realistic POEMS procedure applied to an active training range including details of the artillery round, the training regime and the location.

\subsection{The training area}

Training takes place in an area of $640 \mathrm{~km}^{2}(40 \times 16$ $\mathrm{km}$ ) within a larger estate in the southwest of England. The estate also contains approximately 2300 archaeological sites including features dating back to $4000 \mathrm{BC}$, along with evidence of Roman settlements. The southwest of England is a large area of chalk grassland, one of the largest in northwest Europe, and accounts for $40 \%$ of the total area of this habitat remaining in the UK. The estate and training area geology primarily comprise of chalk deposited during the Upper Cretaceous (100 million years ago). The chalk strata in this area can be divided into three broad categories:

- Upper chalk - a white, uniform, massively-bedded deposit, up to $400 \mathrm{~m}$ in thickness, of almost pure calcium carbonate;

- Middle chalk - a white homogenous deposit with occasional marl deposits;

- Lower chalk - relatively soft and greyish in colour, with a clay content that increases with depth.

The training area is located over a major aquifer, with a soil covering that permits high to intermediate levels of leaching. This means that liquid contaminants can readily pass through the soil to the underlying strata and possibly to groundwater. However, because the hydraulic conductivity of the chalk mass is low, water and contaminants are transmitted through fissures in the rock, which are more likely to form in the harder and more brittle chalk bands. Groundwater in the area is potable and is therefore used for the public water supply. Although all of the abstraction points are just outside the central impact area (in which most rounds are fired), the aquifer beneath the central impact area is a catchment for many of the public supply wells, and is therefore closely monitored for pollution. The training area also includes seven different Sites of Special Scientific Interest (SSSI) and is home to 13 species of nationally rare plants, and 70 species of rare invertebrates including several rare butterflies such as the marsh fritillary, Adonis blue and brown hairstreak (Table 2).

It is important to note that approximately 10 $\mathrm{km}^{2}$ of the estate is permanently closed to the public for safety reasons (artillery impact and live firing areas). The training area routinely offers live firing and other facilities for armoured vehicles, artillery, engineers, infantry and aircraft. There is also active management of the airspace over both the estate and its adjacent areas, which is used day and night by military aircraft from all three UK Services, sometimes complemented by NATO aircraft.

Table 2 Summary of training area characteristics

\begin{tabular}{|l|l|}
\hline Area & $640 \mathrm{~km}^{2}$ in intermittent use \\
\hline Features & Embedded in larger estate. \\
\hline Geology & Mostly upper chalk \\
\hline Hydrogeology & $\begin{array}{l}\text { Overlying a major aquifer, with moderate } \\
\text { likelihood of pollutant leaching }\end{array}$ \\
\hline Groundwater & Potable water abstraction and supply \\
\hline Land use & $\begin{array}{l}\text { Flanked by public roads to the east and west, } \\
\text { bordered by numerous villages. } \\
\text { Land north and south is predominantly used for } \\
\text { farming. } \\
\text { Some recreational use. }\end{array}$ \\
\hline
\end{tabular}

\subsection{The 105-mm howitzer artillery round}

The tactical applications and worldwide stockpiles of the 105-mm high-explosive artillery round make it ideal for this case study. Several manufactures produce this type of round and they can be approached for key information [13]-[17]. Technical specifications vary between manufacturers reflecting the use of different facilities, assembly lines and materials. For this study, we selected the 105-mm HE lightgun [18]. This device weighs $15.1 \mathrm{~kg}$ and the payload is $2.5 \mathrm{~kg}$ TNT/RDX (L31 type) with a lead azide-based L116 multi-role fuze (Figure 2).
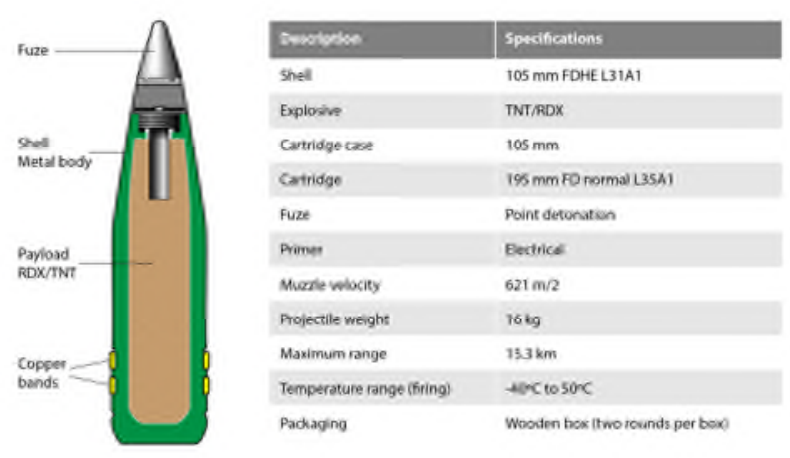

Figure 2 Description of the 105-mm howitzer round.

\subsection{The training regime}

The range serves four artillery battalions, each carrying out two training sessions per year. The military, including the USA and UK, categorise the $105-\mathrm{mm}$ round as light artillery, mainly used for field or airborne artillery battalions and batteries. In modern warfare, and for the purposes of this article, a typical field artillery battalion consists of three artillery batteries each led by a captain. A battery in turn includes 6-8 howitzers, each operated by a six-man crew, so a battalion would have 18-24 howitzers at its disposal.

Each howitzer fires up to 100 rounds per training session, i.e. 1800-2400 rounds per battalion, making a total of 3600-4800 rounds per battalion per year. Therefore, the total number of rounds fired on a training range used by four battalions will be 14,400- 
19,200 per year. We selected the lowest figure $(14,400$ rounds) as the basis for the POEMS case study.

The following section will outline in more detail what POEMS is and how it is implemented in the theoretical scenario described above. It will include the anticipated results at each stage of the POEMS process and the content and description of the corresponding documentation.

\section{Results and discussion}

POEMS consists of eight core EMPs based on ISO14001 [5] and ISO14040 [7], which are designed to be flexible in their application. Before starting the formal POEMS process, it is helpful to contextualise the project to gain a high-level understanding of the equipment. This can be visualised by creating a context diagram outlining the CADMID cycle and the activities associated with each life-cycle phase. Each activity in the context diagram usually requires materials and/or energy as an input (e.g. fuel) and is associated with outputs that have a potential environmental impact (e.g. emissions). As part of the POEMS procedure, inputs and outputs are described as the 'embodied' and 'emitted' aspects, respectively (Figure 3). The POEMS process can then be implemented, usually in a linear manner, from EMP01 through to EMP07, as shown for the $105-\mathrm{mm}$ round below and summarised in Table 3. EMP08 is a continuous review, which runs throughout the POEMS process and beyond.

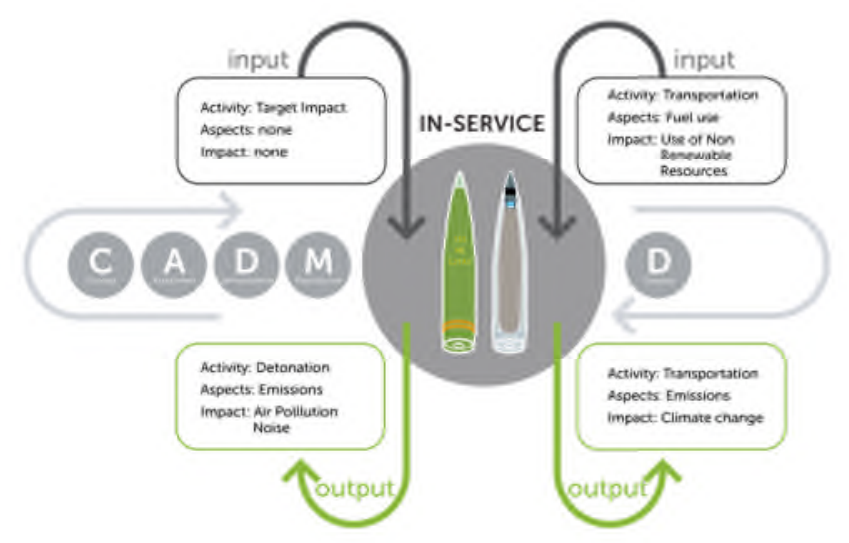

Figure 3: A simplified context diagram for the 105-mm round during the in-service phase, detailing two activities: target impact and transportation, and the associated aspects and impacts.

Where possible, POEMS should be applied to the whole CADMID cycle. However, this paper only considers the target impact activity within the inservice phase because the $105-\mathrm{mm}$ round has already been manufactured and is in use. In reality, the POEMS implementation would also consider the disposal phase as early as possible.

The first phase of POEMS is used to gather and record information about the equipment, such as key stakeholders and standards. It is important to engage with stakeholders, to understand their concerns and requirements, and to collect information pertinent to the project such as training schedules, manufacturer and purchasing information, and user requirements. This also helps to establish multiple communication pathways, which should be recorded in a communications plan. The core stakeholders for the $105-\mathrm{mm}$ round include the military using the munition for training, and estates concerned about soil and water contamination or noise. The latter is a particular concern because the training area is located near several local villages and a noise nuisance could be negatively perceived by the public. Other stakeholders (inner and outer, see Table 3) include the Environment Agency, archaeologists, and local farmers who protect and use the land.

The second requirement is a list of all standards relevant to the activities conducted with the 105-mm round, including relevant UK and international legislation, MOD policy and site orders for anywhere the $105-\mathrm{mm}$ round is stored, transported or used. The MOD translates legislation into policy through Joint Service Publication (JSP) documents, such as the environmental protection policy (JSP418). For example, the Environmental Protection Act 1990 (EPA 1990) [19] regulates emissions to air, land and water, and also covers statutory noise nuisance regulations. However, EPA 1991 [19] does not stipulate daytime noise limits and so the standards register was supplemented with the Control of Noise at Work Regulations 2005 [20], which stipulates that noise should be kept below Health and Safety limits (87 decibels). Compliance with the EU Water Framework Directive [21], through the Water Act 2003 [22] in the UK, was particularly relevant in this case because the training area is located over an aquifer. This aquifer feeds potable water sources and must not breach regulatory limits for certain substances such as aluminium $(200 \mu \mathrm{g} / \mathrm{l})$, copper $(2 \mu \mathrm{g} / \mathrm{l})$, lead $(10 \mu \mathrm{g} / \mathrm{l})$ and mercury $(1 \mu \mathrm{g} / \mathrm{l})$ [23]. Single firings of the $105-\mathrm{mm}$ round are unlikely to breach any legislation, but the training schedule shows that up to 14,400 rounds are fired each year and the cumulative effects may be significant.

EMP02 states that the boundaries of POEMS implementation are established through a 'screening and scoping' process. However, the context diagram (Figure 3) captured the important information and was useful during the information-gathering phase (EMP01). At this stage, the boundaries were officially defined to cover only the in-service phase and to disregard the firing platform because this was already covered by a separate POEMS process. This stage also requires the identification of all activities associated with the 105-mm round, their embodied and emitted aspects, and anticipated environmental impacts. No aspects or impacts associated with embodied materials were identified for the $105-\mathrm{mm}$ round because these were deemed to be associated with the firing platform (e.g. burning the propellant to fire the round). However, aspects were identified for the detonation of the $105-\mathrm{mm}$ round, such as the 
gaseous detonation products, blast wave and noise. The products from a full-order detonation of a 105-mm round are listed in Table 4.

The emitted chemicals listed in Table 4 were calculated using data available in the literature [24][27]. The calculations were based on the reaction conditions (confinement, high pressures, the rate of reaction and the lack of oxygen available) and the deviation from typical products expected from a combustion reaction (such as $\mathrm{CO}_{2}$ and $\mathrm{H}_{2} \mathrm{O}$ ).

Table 4 Embodied and emitted aspects (materials) for a single 105-mm high-explosive round.

\begin{tabular}{|c|c|c|c|c|}
\hline \multirow[b]{2}{*}{ Material } & \multicolumn{2}{|c|}{ Embodied } & \multicolumn{2}{|c|}{ Emitted } \\
\hline & Component & $\begin{array}{c}\text { Quantity } \\
(\mathrm{kg})\end{array}$ & Description & $\begin{array}{l}\text { Quanti } \\
\text { ty }(\mathrm{kg})\end{array}$ \\
\hline \multirow{3}{*}{ Metals } & Brass & \multirow{3}{*}{13.5} & Metal & \multirow{3}{*}{13.5} \\
\hline & Copper & & fragments & \\
\hline & Steel & & and fumes & \\
\hline \multirow{16}{*}{ Explosives } & \multirow{10}{*}{ TNT } & \multirow{10}{*}{0.975} & $\mathrm{CO}_{2}$ & 0.236 \\
\hline & & & $\mathrm{CO}$ & 0.353 \\
\hline & & & $\mathrm{CH}_{4}$ & 0.004 \\
\hline & & & $\mathrm{H}_{2} \mathrm{O}$ & 0.005 \\
\hline & & & $\mathrm{C}_{2} \mathrm{H}_{2}$ & 0.014 \\
\hline & & & $\mathrm{HCN}$ & 0.014 \\
\hline & & & $\mathrm{H}_{2}$ & 0.008 \\
\hline & & & $\mathrm{N}_{2}$ & 0.162 \\
\hline & & & $\mathrm{NH}_{4} \mathrm{HCO}$ & 0.035 \\
\hline & & & $\mathrm{C}$ & 0.093 \\
\hline & \multirow{5}{*}{ RDX } & \multirow{5}{*}{1.5} & $\mathrm{HCN}$ & 0.367 \\
\hline & & & $\mathrm{N}_{2} \mathrm{O}$ & 0.299 \\
\hline & & & $\mathrm{H}_{2} \mathrm{O}$ & 0.122 \\
\hline & & & $\mathrm{NO}$ & 0.204 \\
\hline & & & $\mathrm{CH}_{2} \mathrm{O}$ & 0.204 \\
\hline & Wax & 0.025 & \multicolumn{2}{|c|}{ Negligible } \\
\hline \multirow{2}{*}{$\begin{array}{l}\text { Primers } \\
\text { and fuse }\end{array}$} & Lead azide & \multirow[b]{2}{*}{ (1) } & \multicolumn{2}{|c|}{ Lead contamination } \\
\hline & $\begin{array}{l}\text { Booster } \\
\text { charge }\end{array}$ & & \multicolumn{2}{|c|}{ Negligible } \\
\hline
\end{tabular}

The impact priority evaluation (EMP03) is the crucial element of the POEMS procedure because it ranks all of the environmental impacts associated with the equipment to determine the priorities for mitigation or management. The impact priority evaluation can be undertaken using an Environmental Features Matrix (EFM) on a spreadsheet that automatically calculates the priority list by multiplying the severity and frequency scores (Table 3). If the EFM score is below 12 for each activity, the environmental impact can be considered minimal and no further action is required other than the continuous review process. If any activities score between 12 and 24, the environmental impact is significant and may require mitigation, and if the score is above 24 the impact is severe and should be re-assessed (and if possible stopped).

In this case study, the priority evaluation was undertaken for one full year of training with the 105$\mathrm{mm}$ round, therefore accounting for cumulative effects (approximately 14,400 rounds fired). Most aspects scored lower than 12 on the EFM, e.g. dispersion of metal shrapnel, blasting effects and gaseous emissions, indicating they would have a low to negligible environmental impact. However, two of the aspects scored 12, which is the threshold between minimal and significant impact, and may therefore require further investigation. One of the concerns was the contamination of soil and water by the lead azide primary explosive within the fuze, which may cause the deposition of lead particles around the impact site. Another concern was noise nuisance, where the score was higher to pre-empt the aforementioned potential for negative public perception, even though the actual noise from the detonations would be well below Health and Safety recommendations for nearby populations (87 decibels). By flagging the potential for noise nuisance at this stage, it would be possible to incorporate into the POEMS procedure the management of public perception towards noise.

The collated documentation from the first three EMPs forms the basis of an environmental case and thus the foundation of the POEMS documentation. At this point, an Environmental Screening and Scoping (ESS) report is usually produced along with an Environmental Impact Statement (EIS), detailing the most significant environmental impacts. An EIS is a non-technical summary of the POEMS implementation such that any interested stakeholder would be able to understand the outcomes.

If the priority evaluation (EMP03) indicates the equipment has a limited environmental impact, then it may be unnecessary to carry out the remaining stages of POEMS. In such cases, the POEMS procedure would be summarised in a report and regular reviews would be carried out to capture any changes. However, most POEMS implementations do identify some aspects that cross the minimal threshold score (12) and require further investigation in the form of an Environmental Impact Assessment (EIA). EMP04 describes how to outline a strategy for the further assessment of identified environmental impacts. For the $105-\mathrm{mm}$ round, the EFM established the potential for lead contamination in the local water and soil, and therefore during the EIA planning stage we would consider contracting specialists to investigate how much lead is deposited on the training range per year. However, we also looked at other POEMS implementations for similar equipment using the same training area and found that it was unnecessary to conduct full-scale research because sufficient work had been carried out previously, and on-site monitoring for lead concentrations in potable water sources was already in place.

As mentioned above, the potential for noise nuisance was considered based on anticipated negative perception, and a noise level monitoring programme was suggested during training with the $105-\mathrm{mm}$ round. Currently there is no breach of statutory noise levels, so no EIA would be required. However, a report should be produced listing all decisions taken during the POEMS process, a summary of previous research and links to full reports, and a record of current monitoring programmes. 
Table 3 Outline of the POEMS procedures (EMPs 1-8) and the outputs associated with the 105-mm round

\begin{tabular}{|c|c|c|c|c|c|c|c|c|}
\hline EMP & $\begin{array}{l}\text { Procedures } \\
\text { (relating to activity: } \\
\text { target impact) }\end{array}$ & Expected output & \multicolumn{6}{|c|}{ Outcome for case study } \\
\hline \multirow[t]{2}{*}{1} & $\begin{array}{l}\text { Stakeholders and } \\
\text { standards } \\
\text { identification }\end{array}$ & $\begin{array}{l}\text { A stakeholders register: } \\
\text { detailing core, inner and } \\
\text { outer }^{a} \text { stakeholders including } \\
\text { information and relevant } \\
\text { requirements. }\end{array}$ & \multicolumn{6}{|c|}{$\begin{array}{l}\text { Core: Users (safety, handling, requirements), POEMS project } \\
\text { delivery team. } \\
\text { Inner: MOD estates organisation (where and when to fire), } \\
\text { environmental test and assurance, programme managers. } \\
\text { Outer: Environment Agency (monitoring), neighbours (famers), } \\
\text { archaeologists (define usable areas, control water quality, } \\
\text { noise (when/how often) and vibration). }\end{array}$} \\
\hline & $\begin{array}{l}\text { Identification of } \\
\text { relevant legislation }\end{array}$ & $\begin{array}{l}\text { A legislation register to } \\
\text { ensure compliance with UK } \\
\text { or strictest relevant } \\
\text { legislation in area of use } \\
\text { including guidance, policy } \\
\text { and associated documents. }\end{array}$ & \multicolumn{6}{|c|}{$\begin{array}{l}\text { A non-exhaustive list includes: Environmental Protection Act } \\
\text { 1991, including water, land and air emissions; Control of Noise } \\
\text { at Work Regulations (2005); EU Water Framework Directive } \\
\text { (2012); Water Act (2003) and JSP418. }\end{array}$} \\
\hline 2 & $\begin{array}{l}\text { Screening and } \\
\text { scoping }\end{array}$ & $\begin{array}{l}\text { List of embodied and } \\
\text { emitted }{ }^{b} \text { aspects (causes) } \\
\text { and impacts (effects) of the } \\
\text { activities. Setting the } \\
\text { boundaries of the project. }\end{array}$ & \multicolumn{6}{|c|}{$\begin{array}{l}\text { Embodied aspects/impacts: There are no embodied aspects } \\
\text { (although there are embodied materials) in this case because } \\
\text { we did not consider the firing platform (howitzer) as part of this } \\
\text { POEMS project. } \\
\text { Emitted aspects: emissions, blast. } \\
\text { Emitted impacts: cumulative effects; air pollution (noxious } \\
\text { gasses), nuisance, cumulative land contamination from metal } \\
\text { scraps/fumes/ other constituents. }\end{array}$} \\
\hline \multirow{5}{*}{3} & \multirow{5}{*}{$\begin{array}{l}\text { Impact priority } \\
\text { evaluation }\end{array}$} & \multirow{5}{*}{$\begin{array}{l}\text { A prioritization table } \\
\text { (environmental feature } \\
\text { matrix, EFM) that ranks } \\
\text { aspects and impacts from } \\
\text { both embodied and emitted } \\
\text { materials. Priorities are } \\
\text { determined by multiplying a } \\
\text { severity score (1-6) and a } \\
\text { frequency score (1-6) } \\
\text { resulting in EFM values of 1- } \\
36 \text {. }\end{array}$} & \multirow{2}{*}{$\begin{array}{l}\text { Aspect } \\
\text { (Detonation) }\end{array}$} & \multicolumn{2}{|c|}{ Receptor } & \multirow{2}{*}{ Severity } & \multirow{2}{*}{ Freq. } & \multirow{2}{*}{ Priority } \\
\hline & & & & Water & Human & & & \\
\hline & & & $\begin{array}{l}\text { Lead fumes } \\
\text { (from fuze) }\end{array}$ & $x$ & & 4 & 3 & 12 \\
\hline & & & Noise & & $X$ & 1 & 3 & 3 \\
\hline & & & \multicolumn{6}{|c|}{$\begin{array}{l}\text { A representative EFM used for this case study is provided as } \\
\text { Supplementary Data. }\end{array}$} \\
\hline 4 & $\begin{array}{l}\text { Environmental } \\
\text { impact assessment } \\
\text { (EIA) plan }\end{array}$ & $\begin{array}{l}\text { Outline strategy for } \\
\text { conducting an environmental } \\
\text { impact assessment, if the } \\
\text { priority established in the } \\
\text { EFM is greater than } 12 \text {. }\end{array}$ & \multicolumn{6}{|c|}{$\begin{array}{l}\text { In this case the impact priority evaluation showed that there } \\
\text { were two scores of } 12 \text {, associated with soil/water } \\
\text { contamination caused by lead azide combustion products. } \\
\text { Noise impacts did not score more than } 12 \text {, although perception } \\
\text { issues could require some mitigation. }\end{array}$} \\
\hline 5 & EIAs and reporting & $\begin{array}{l}\text { Environmental impact } \\
\text { assessment, using experts if } \\
\text { required, and preparation of } \\
\text { an EIA report. }\end{array}$ & \multicolumn{6}{|c|}{$\begin{array}{l}\text { A specialist would assess the level of noise from the activity } \\
\text { and compare this to threshold levels. }\end{array}$} \\
\hline 6 & $\begin{array}{l}\text { Environmental } \\
\text { management plan } \\
\text { (objectives and } \\
\text { targets) }\end{array}$ & $\begin{array}{l}\text { Setting specific, measurable, } \\
\text { achievable, realistic and } \\
\text { time-bound (SMART) } \\
\text { objectives to meet targets set } \\
\text { within the environmental } \\
\text { management system. }\end{array}$ & \multicolumn{6}{|c|}{$\begin{array}{l}\text { Noise: Monitoring; rotating and/or re-locating firing areas; } \\
\text { continuous communication through newsletters and periodic } \\
\text { meetings with stakeholders. } \\
\text { Lead: Monitor lead concentrations in local water supplies to } \\
\text { ensure there is no breach of threshold levels at any time (the } \\
\text { UK drinking water limit for lead is } 10 \mu \mathrm{g} / \mathrm{l} \text { ). }\end{array}$} \\
\hline 7 & Operational controls & $\begin{array}{l}\text { Controls to achieve the } \\
\text { targets set in EMP06. }\end{array}$ & \multicolumn{6}{|c|}{$\begin{array}{l}\text { Writing standard operating procedures such as the rotation of } \\
\text { firing areas, and stating procedures if threshold levels are } \\
\text { breached. }\end{array}$} \\
\hline 8 & Continuous review & $\begin{array}{l}\text { Continuous improvements of } \\
\text { EMS outputs at specific set } \\
\text { of intervals or trigger points. } \\
\text { Record all reviews and } \\
\text { outcomes/changes triggered. }\end{array}$ & \multicolumn{6}{|c|}{$\begin{array}{l}\text { Undertake scheduled internal reviews of POEMS to ensure the } \\
\text { consistency of the plan-do-check-act cycle. A review would be } \\
\text { undertaken due to changes in the firing schedule, } \\
\text { manufacturer of the round, person responsible for POEMS. }\end{array}$} \\
\hline
\end{tabular}

${ }^{a}$ Core stakeholders = directly involved with project (daily basis); inner stakeholders = some involvement with project on a regular basis; outer stakeholders = interest in project, but minimal contact. ${ }^{b}$ Embodied = input materials/energy (e.g. fuel); emitted = output materials/energy (e.g. emissions). 
At this point, objectives and targets are usually set in order to ensure continual compliance with legislation and to address stakeholder concerns wherever possible. For POEMS, objectives are established to achieve a positive environmental effect, and targets provide verifiable evidence that each objective has been met. Best practice is to ensure that targets are specific, measurable, achievable, relevant and time-bound (SMART). For the $105-\mathrm{mm}$ round, there was no record of any lead contamination on the site, and noise nuisance was well below statutory limits. In addition, training with the $105-\mathrm{mm}$ round is conducted alongside other training activities for which lead and noise monitoring is already in place so the data can be assimilated for this particular round.

Standard operating procedures (SOPs) written during EMP07 describe how the objectives will be met within the required time. For the 105-mm round, the objectives were to ensure continued compliance with the threshold for lead contamination in soil and groundwater $(10 \mu \mathrm{g} / \mathrm{l})$ [23] as well as statutory noise limits. To achieve these objectives, the SOPs included timetables for rotation of the firing area, plans for monitoring and recording lead concentrations and noise levels, and emergency controls should lead levels in the local drinking water exceed the threshold.

The entire body of documentation generated during the POEMS process forms the EMS for the $105-\mathrm{mm}$ round. Once the Environmental Management Plan was in place, annual reviews were planned, with documentation prepared to record any changes to the POEMS after the review. Trigger points were also identified, such as planned changes in the training schedule, or changes introduced during the manufacture of the round. Unplanned events, such as incidents of lead contamination, a change in legislation, or a change in the personnel responsible for POEMS would also trigger a review.

\section{Conclusions}

The UK MOD POEMS process is an effective EMS that has the ability to identify monitor and manage any environmental aspects and impacts related to the use of defence equipment. The process itself is based on ISO 14001 and ISO 14040, but has been designed to be applicable to individual projects rather than whole sites, the latter being difficult for MOD sites due to the diverse and fluctuating activities and the transient populations. Because POEMS is based on two well-known international standards, stakeholders and personnel are immediately familiar with many aspects of the process, and regulatory bodies can be assured that MOD environmental management aims to achieve the highest standards.

POEMS consists of eight core EMPs that are designed to be flexible and straightforward to implement by nonspecialists. The case study described herein was based on a 105-mm artillery round and provides insight into the practical aspects of POEMS by detailing how each EMP is implemented based on theoretical outcomes. The overall conclusion from this particular case study is that firing the $105-\mathrm{mm}$ round would cause a negligible environmental impact, although issues may arise due to the large number of rounds fired each year specifically concerning lead residues in soil and groundwater.

Another benefit to POEMS is the ability to address non-conventional issues such as public perception, which is particularly of interest to the MOD. For the 105-mm round, noise issues have the potential to generate a negative perception even if they do not breach statutory limits. Even so, as part of the POEMS procedure, anticipated perception issues were mitigated by implementing noisemonitoring regimes, which might not be identified when applying ISO 14001.

\section{Acknowledgements}

The authors would like to thank Dr Geoff Hooper and Dr Richard M Twyman for their valuable comments. We also aknowledge the Centre for Defence Chemistry, Cranfield University and the UK-MOD.

\section{References}

[1] I. . Hui, A. H. . Chan, and K. . Pun, "A study of the Environmental Management System implementation practices," J. Clean. Prod., vol. 9, no. 3, pp. 269-276. 2001.

[2] M. A. Balzarova and P. Castka, "Underlying mechanisms in the maintenance of ISO 14001 environmental management system," J. Clean. Prod., vol. 16, no. 18, pp. 19491957. 2008.

[3] M. Lozano and J. Vallés, "An analysis of the implementation of an environmental management system in a local public administration," $J$. Environ. Manage., vol. 82, no. 4, pp. 495-511, 2007. 
[4] T. B. Ramos, I. Alves, R. Subtil, and J. J. de Melo, "The state of environmental performance evaluation in the public sector: the case of the Portuguese defence sector," J. Clean. Prod., vol. 17, no. 1, pp. 36-52, 2009.

[5] ISO - International Organization for Standardization, ISO 14001 Environmental Management Systems - Specification with Guidance for Use. Geneva, Switzerland.: International Organization for Standardization, 1996.

[6] UK-MOD, POEMS - Project - Oriented Environmental Management System Manual. Bristol, United Kingdon: MOD Defence Equipment and Support, 2007.

[7] ISO - International Organization for Standardization, ISO $\quad 14040$ International Standard. Environmental management - Life cycle assessment Principles and framework. Geneva, Switzerland.: International Organisation for Standardization, 2006.

[8] ISO - International Organization for Standardization, ISO 14044 Environmental Management: Life Cycle Assessment, Life Cycle Impact Assessment. Geneva, Switzerland.: International Organisation for Standardization, 2006.

[9] A. Tukker, "Life cycle assessment as a tool in environmental impact assessment," Environ. Impact Assess. Rev., vol. 20, no. 4, pp. 435-456, 2000.

[10] USDoD (US Department of Defence), MIL STD 882-C-SYSTEM SAFETY PROGRAM REQUIREMENTS. 1993.

[11] USDoD (US Department of Defence), MIL STD 882-D - Standard Practice for System Safety, no. January 1993. Washington, USA: USA, 2000.

[12] USDoD (US Department of Defence), MIL STD 882-E - Standard Practice for System Safety, no. February 2000. Washington, USA: USA, 2012.

[13] IMBEL, "IMBEL,". [Online]. Available: www.imbel.gov.br. 2016.

[14] Emgepron, "Emgepron," 2016. [Online]. Available:

https://www.emgepron.mar.mil.br/index /english/index.php. [Accessed: 26-Jan2016].

[15] Eurenco, "Eurenco Group," 2016. [Online]. Available: http://www.eurenco.com. [Accessed: 25-Jan-2016].

[16] RAFAEL Advanced Defense Systems,
"RAFAEL Advanced Defense Systems," 2016. [Online]. Available: http://www.rafael.co.il/Marketing/203en/Marketing.aspx. [Accessed: 26-Jan2016].

[17] baesystems, "BAEsystems," 2016. [Online]. Available: http://www.baesystems.com/en/home?r =GB. [Accessed: 26-Jan-2016].

[18] UK-MOD- Army, "Lightgun Howitzer," 2016. [Online]. Available: http://www.army.mod.uk/equipment/23 275.aspx. [Accessed: 26-Jan-2016].

[19] Parliament of the United Kingdom, Environmental Protection Act 1991. London: Parliament of the United Kingdom, 1991.

[20] Parliament of the United Kingdom, Control of Noise at Work Regulations 2005. 2005.

[21] European Commission, EU Water Framework Directive. Brussels: European Commission, 2012.

[22] Parliament of the United Kingdom, Water Act 2003. 2003.

[23] Government of England and Wales and UK Parliment, No . 3184 - WATER, ENGLAND AND WALES - The Water Supply (Water Quality) Regulations 2000, no. 3184. London: Parliament of the United Kingdom, 2000.

[24] R. R. Meyer, J. Kohler, A. Homburg, J. Köhler, and A. Homburg, Explosives, 6th, Compl. Weinheim: Wiley-VCH Verlag GmbH, Weinheim, 2007.

[25] T. Urbanskl, "Chemistry and technology of explosives, Vol. 1." pp. 249-253, 1985.

[26] T. Urbanski, Chemistry and Technology of Explosives - v.3, 1st ed. Warszawa: Polish Scientific Publishers, 1967.

[27] T. R. Botcher and C. a. Wight, "Explosive Thermal Decomposition Mechanism of RDX," J. Phys. Chem., vol. 418, no. 98, pp. 5441-5444, 1995. 